\title{
Evaluation of Elite Sorghum [Sorghum bicolor (L.) Moench] Germplasm Lines for Morphological Traits
}

\author{
Naveen Sihag*, Shubham Johari, Baishali Mishra, \\ P. K. Shrotria and P. K. Pandey
}

Department of genetics and plant breeding, Govind Ballabh Pant University of Agriculture and Technology, Pantnagar-263145, India

*Corresponding author

\begin{tabular}{|l|}
\hline Ke y w o r d s \\
Accessions, Genetic \\
diversity, Sorghum, \\
Morphological \\
traits, Races
\end{tabular}

A B S T R A C T

This study was performed at Instructional dairy farm, Govind Ballabh Pant University of agriculture and technology during Kharif season, 2017 to evaluate and characterize 96 sorghum accessions for various morphological and fodder yield parameters. Highest Shannon index was recorded for races (1.47) followed by glume color (1.33), ear head compactness (1.176) and glume covering (1.117) revealed the greater variability for these qualitative traits. The results of this study indicate that significant genetic diversity exists among the sorghum accessions.

\section{Introduction}

Sorghum [Sorghum bicolor (L.) Moench] also known as Jowar has originated in Africa about 5000 - 8000 years ago (De Candolle 1890). Sorghum is the fifth most important cereal crop providing food and fodder throughout the world (Doggett 1988). It is adapted to a wider range of stress conditions like salt and drought and known as a high-energy, drought tolerant crop because of its efficiency. It is planted in those areas which are considered to be hot and too dry for other cereals, because of its tolerance to heat and drought stress (Poehlman, 1987). Sorghum in general possesses a wide range of genetic variability. Adequate variability provides options from which selections are made for improvement and possible hybridization.

Introgression of new genetic diversity through hybridization with selected germplasm is one way to increase genetic variation in breeding populations, the base upon which gain from selection depends (Guedira et al., 2000).

This study was conducted to classify the germplasm on the basis of frequency of visual characters. Different characters have different states of expression. 


\section{Materials and Methods}

The present study was conducted at the Instructional Dairy Farm of the Govind Ballabh Pant University of Agriculture and Technology, Pantnagar, Uttarakhand, India during Kharif 2017. 96 germplasm accessions were used for the study and planted in an Augmented Block Design. Each genotype were sown in two rows of 3 metre length with a row spacing of $45 \mathrm{~cm}$. Recommended package of practices were followed to grow the normal healthy crop. An average rainfall of $948.6 \mathrm{~mm}$ is experienced annually. Data was recorded on different types of morphological traits of 96 germplasm lines.

\section{Results and Discussion}

An evaluation was done to classify the sorghum germplasm on the basis of morphological traits into different categories. Sorghum has a wide range of variability, it has five different races viz., bicolor, kafir, durra, caudatum and guinea. Morphological characters have different states of expression and the number of plants coming under the different categories is calculated in this study. Frequency percentage and Shannon index is calculated. Higher value of Shannon index reveals greater variability in these qualitative traits. The observations are presented in the Table 1.

Table.1 Classification of Sorghum germplasm on the basis of frequency of visual characteristics

\begin{tabular}{|c|c|c|c|c|c|}
\hline $\begin{array}{l}\text { S. } \\
\text { No. }\end{array}$ & Characteristics & States of expression & $\begin{array}{c}\text { No. of } \\
\text { genotypes }\end{array}$ & $\begin{array}{c}\text { Frequency } \\
\%\end{array}$ & $\begin{array}{l}\text { Shannon } \\
\text { index }\end{array}$ \\
\hline 1 & Leaf pigmentation & $\begin{array}{l}\text { Tan } \\
\text { Non } \tan \end{array}$ & $\begin{array}{l}57 \\
39\end{array}$ & $\begin{array}{l}59.3 \\
40.6\end{array}$ & 0.675 \\
\hline 2 & Leaf colour & $\begin{array}{l}\text { Light green } \\
\text { Medium green } \\
\text { Dark green }\end{array}$ & $\begin{array}{l}16 \\
48 \\
42\end{array}$ & $\begin{array}{l}16.66 \\
39.5 \\
43.7\end{array}$ & 1.027 \\
\hline 3 & Mid rib colour & $\begin{array}{l}\text { White } \\
\text { Green }\end{array}$ & $\begin{array}{l}40 \\
56\end{array}$ & $\begin{array}{l}41.66 \\
58.33\end{array}$ & 0.679 \\
\hline 4 & Ear head shape & $\begin{array}{l}\text { Pyramidal } \\
\text { Symmetric } \\
\text { Panicle broader in upper part } \\
\text { Panicle broader in lower part }\end{array}$ & $\begin{array}{c}30 \\
55 \\
3 \\
8\end{array}$ & $\begin{array}{c}31.25 \\
57.29 \\
3.12 \\
8.33\end{array}$ & 0.997 \\
\hline 5 & $\begin{array}{l}\text { Ear head } \\
\text { compactness }\end{array}$ & $\begin{array}{l}\text { Loose } \\
\text { Semi loose } \\
\text { Semi compact } \\
\text { Compact }\end{array}$ & $\begin{array}{c}28 \\
4 \\
20 \\
44\end{array}$ & $\begin{array}{c}29.16 \\
4.16 \\
20.83 \\
45.83\end{array}$ & 1.176 \\
\hline 6 & Glume colour & $\begin{array}{l}\text { Grayed yellow } \\
\text { Grayed orange } \\
\text { Grayed red } \\
\text { Grayed purple }\end{array}$ & $\begin{array}{l}16 \\
36 \\
26 \\
18\end{array}$ & $\begin{array}{c}16.66 \\
37.5 \\
27.08 \\
18.75\end{array}$ & 1.334 \\
\hline 7 & Glume covering & $\begin{array}{l}\text { Short }(50 \% \text { of grain covered) } \\
\text { Medium ( } 75 \% \text { of the grain } \\
\text { covered) } \\
\text { Long ( } 100 \% \text { of the grain covered) } \\
\text { Very long (longer than the grain) }\end{array}$ & $\begin{array}{c}5 \\
25 \\
52 \\
14\end{array}$ & $\begin{array}{c}5.20 \\
26.04 \\
54.16 \\
14.58\end{array}$ & 1.117 \\
\hline 8 & Presence of awns & Present & 27 & 28.12 & 0.594 \\
\hline
\end{tabular}




\begin{tabular}{|c|c|c|c|c|c|}
\hline & & Absent & 69 & 71.87 & \\
\hline 9 & Seed colour & $\begin{array}{l}\text { Grayed yellow } \\
\text { Grayed orange } \\
\text { Grayed purple }\end{array}$ & $\begin{array}{l}36 \\
37 \\
23\end{array}$ & $\begin{array}{c}37.5 \\
38.54 \\
23.95\end{array}$ & 1.077 \\
\hline 10 & Seed lusture & $\begin{array}{l}\text { Lustrous } \\
\text { Non lustrous }\end{array}$ & $\begin{array}{l}50 \\
46\end{array}$ & $\begin{array}{l}52.08 \\
47.91\end{array}$ & 0.692 \\
\hline 11 & Race & $\begin{array}{l}\text { Bicolor } \\
\text { Caudatum } \\
\text { Guinea } \\
\text { Kafir } \\
\text { Durra }\end{array}$ & $\begin{array}{l}13 \\
39 \\
20 \\
14 \\
10\end{array}$ & $\begin{array}{l}13.54 \\
40.62 \\
20.83 \\
14.58 \\
10.41\end{array}$ & 1.479 \\
\hline
\end{tabular}

Highest Shannon index was recorded for races (1.47) followed by glume color (1.33), ear head compactness (1.176) and glume covering (1.117). A diversity index is a quantitative measure that reflects how many different types there are in a dataset. It is most often calculated as follows:

$\mathrm{H}^{\prime}=-\sum_{i=1}^{R} P i \operatorname{In} P i$

In ecology, $p_{i}$ is often the proportion of individuals belonging to the $i$ th species in the dataset of interest.

Dong et al., 2001, Tatineni et al., 1996, Ghafoor et al., 2002 and Malik et al., 2011 also observed wide range of variability for morphological characters.

\section{Conflict of interest}

The authors declare that they have no conflict of interest.

\section{References}

De Candolle, A., 1884. Origin of Cultivated Plants, Hafner Publishing Company, New York.

Doggett, H. 1988. Sorghum. Longman Scientific, and Technical, London.
Dong, Y.S., B.C. Zhuang, L.M. Zhao, H.Sun and M.Y. He. 2001. The genetic diversity of annual wild soybeans grown in China. Theor. Appl Genet., 103: $98-103$.

Ghafoor, A., Ahmad, Z., Qureshi, A. S. and Bashir, M. 2002. Genetic relationship in Vigna mungo (L.) Hepper and V. radiata (L.) R. Wilczek based on morphological traits and SDSPAGE. Euphytica, 123(3), 367-378.

Guedira, G.L.B., J.A. Thompson, R.L. Nelson and M.L. Warburton. 2000. Evaluation of genetic diversity of soybean introductions and North American ancestors using RAPD and SSR markers. Crop Sci., 40: 815-823.

Malik, M. F. A., Ashraf, M. U. H. A. M. M. A. D., Qureshi, A. S. and Khan, M. R. 2011. Investigation and comparison of some morphological traits of the soybean populations using cluster analysis. Pak. J. Bot, 43(2), 12491255.

Poehlman, J. M. 1987. Breeding sorghum and millet. In Breeding field crops (pp. 508-555). Springer, Dordrecht.

Tatineni, V., Cantrell, R. G. and Davis, D. D. 1996. Genetic diversity in elite cotton germplasm determined by morphological characteristics and RAPDs. Crop Science, 36(1), 186-192. 


\section{How to cite this article:}

Naveen Sihag, Shubham johari, Baishali mishra, P. K. Shrotria and Pandey, P. K. 2019. Evaluation of Elite Sorghum [Sorghum bicolor (L.)Moench] Germplasm Lines for Morphological Traits. Int.J.Curr.Microbiol.App.Sci. 8(10): 2488-2491. doi: https://doi.org/10.20546/ijcmas.2019.810.289 